\title{
Zeldzame aandoeningen
}

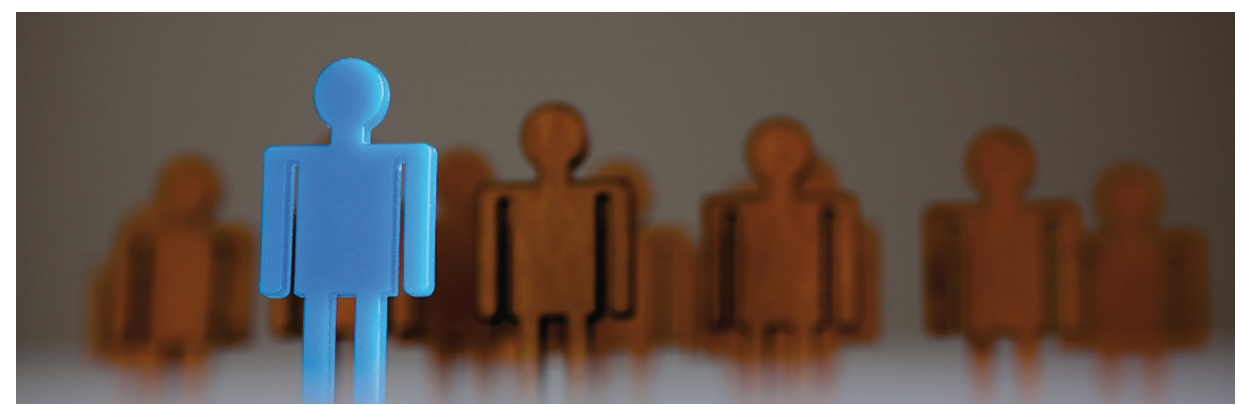

1. Nijnuis deed kwalitatief onderzoek naar ervaringen van ouders van kinderen met een zeldzame ziekte. Met welk doel brengt zij daarvan verslag uit aan huisartsen?

a. Om huisartsen meer begrip te laten krijgen voor de ouders tijdens het diagnosetraject.

b. Om huisartsen zeldzame aandoeningen sneller te laten diagnosticeren.

c. Om huisartsen inzicht te geven in ervaringen van de ouders tijdens het diagnosetraject.

2. De zorgprofessional is tijdens het diagnosetraject belangrijk voor de ouders. Wat vinden ouders tijdens dit traject vooral belangrijk?

a. Dat ze serieus worden genomen.

b. Dat er snelle diagnostiek plaatsvindt.

c. Dat de zorgprofessional over voldoende kennis beschikt.

3. Nijnuis benoemt in haar artikel de gevoelens van de ouders nadat ze de diagnose van hun kind kregen. Welke gemoedstoestand staat dan bij hen op de voorgrond?
a. Ongeloof.
b. Ontreddering.
c. Opluchting.

4. Vier van de vijf zeldzame aandoeningen hebben een genetische component. De genetische afwijking kan zijn doorgegeven van ouders op kind (overerving), maar kan ook spontaan ontstaan in utero (embryonaal) of pas later in het leven. De aandoening komt dan niet in de familie voor. Welke mechanisme komt voor bij zeldzame ziekten?
a. Overerving.
b. Spontane afwijking.
c. Beide.

5. Zeldzame ziekten komen bij minder dan 1 op 2000 personen voor. Als groep zijn zeldzame ziekten echter minder zeldzaam. Hoe vaak komt de totale groep zeldzame ziekten in Nederland voor?
a. Vaak, 1 miljoen Nederlanders hebben een zeldzame ziekte.
b. Weinig, 100.000 Nederlanders hebben een zeldzame ziekte.
c. Sporadisch, 10.000 Nederlanders hebben een zeldzame ziekte.

6. Van de huisarts mag niet worden verwacht dat hij een specifieke zeldzame ziekte diagnosticeert. Nijnuis pleit wel voor awareness, het besef dat er sprake zou kunnen zijn van een zeldzame ziekte. Aanwezigheid van het 'plusteken' is een aanwijzing voor een zeldzame ziekte. In welk geval is er sprake van een plusteken?

a. Een kind met een ontwikkelingsachterstand en een niet-passende onderzoeksbevinding.

b. Een kind met een gewone aandoening met een niet-bijpassend symptoom.

c. Een kind uit een erfelijk belaste familie met een bij de ziekte passend symptoom.
7. De heer Vriens, 56 jaar, merkt dat de kracht in zijn rechterhand minder wordt. Ook voelt hij in zijn rechterarm soms spierkrampen. Bij het lopen kan hij zijn linkervoorvoet niet goed optillen, waardoor deze met een klap op de grond valt. Hij heeft geen tintelingen en geen pijn. Bij onderzoek is de kracht in de rechterhand verminderd en is er een klapvoet links. Er zijn fasciculaties in de linkerarm. De sensibiliteit is intact. Welke diagnose is het meest waarschijnlijk?
a. Amyotrofische lateraal sclerose.
b. Multipele sclerose.
c. Ziekte van Parkinson.

8. De heer De Wit, 28 jaar, kan kort voor het inslapen vaak opeens niets meer bewegen. Het duurt kort en herstelt snel. Hij kan 's nachts niet goed doorslapen en is vaak wakker. Daardoor is hij overdag slaperig en hij kan zijn ogen dan maar moeilijk openhouden. Hij laat overdag zomaar dingen uit zijn handen vallen. Wat is de meest waarschijnlijke diagnose?

a. Idiopathische drop attacks.

b. Narcolepsie.

c. Obstructief slaapapneusyndroom.

d. Partieel complexe epilepsie.

De kennistoets is gemaakt door Henk Folkers, huisarts en toetsdeskundige. Over vragen en antwoorden wordt niet gecorrespondeerd.

\section{GEBRUIKTE BRONNEN}

Nijnuis M, Alma M. Diagnostiek van zeldzame ziekten. Een literatuuronderzoek naar de ervaringen van ouders. Huisarts Wet 2018;61[9]: 14-7.D0l:10.1007/s12445-018-0243-8. Hendriks S, Sollie A, Nijnuis M, Stolper. Zeldzame ziekten: een onmogelijke diagnostische opgave? Huisarts Wet 2016;59[11]:498-501. www.VSOP.nl.

Kuks JBM, Snoek JW. Leerboek klinische neurologie. 18e herziene druk. Houten: Bohn Stafleu van Loghum, 2016.

\section{ANTWOORDEN}

q8 / e L / q9 / es / ग৮ / כ / e己 / כ 